\title{
Diversity in Nutrition and Bioactivity of Momordica cochinchinensis
}

\author{
Dilani Wimalasiri", Terrence Piva*, Tien Huynh ${ }^{\#}$ \\ \# School of Applied Sciences (Biotechnology), RMIT University, PO Box 71, Bundoora 3083, Australia. \\ E-mail: tien.huynh@rmit.edu.au,dilani.wimalasiri@rmit.edu.au \\ * School of Medical Sciences, RMIT University, PO Box 71, Bundoora 3083, Australia \\ E-mail: terry.piva@rmit.edu.au
}

\begin{abstract}
Momordica cochinchinensis (Cucurbitaceae) aril is the richest source of the carotenoids of all known fruits with high anticancer activity. The plant is restricted to South East Asia with diverse morphology and genetic variations. The effect of varietal variations on carotenoids (lycopene and $\beta$-carotene) and anticancer activity was investigated to determine cultivars important for agricultural development. M. cochinchinensis aril samples were collected from 17 provinces within Thailand and Vietnam and compared with samples from Australia. Lycopene and $\beta$-carotene was quantified using HPLC and cytotoxicity on melanoma (MM418C1, D24) and breast cancer (MCF7) cells were assessed using CCK 8 assay. The greatest lycopene content was from Central Vietnam $(6.3 \mathrm{mg} / \mathrm{g})$ and greatest $\beta$-carotene was from Northern Vietnam $(5.7 \mathrm{mg} / \mathrm{g})$. Cytotoxicity was greatest from Northern Vietnam, with $70 \%$ melanoma cell death. The best varieties possessing the highest nutritional and bioactivity identified in this study will be incorporated into future breeding and crop improvement programs.
\end{abstract}

Keywords-Momordica cochinchinensis; melanoma, breast cancer; carotenoids; lycopene; $\beta$-carotene.

\section{INTRODUCTION}

Momordica cochinchinensis (Spreng.) is distributed across South East Asia with the vernacular names gấc in Vietnam, Mak kao in Laos, fahk khao in Thailand and Bhat kerala in India [1,2]. The species is diverse with genetic and phenotypic variations $[3,4]$. The fruit is the richest source of lycopene and $\beta$-carotene of all known fruits and vegetables [5]. These carotenoids are bio-active and contribute to a variety of health benefits including antioxidant, anticancer, cardio-protective and anti-inflammatory effects [6-8]. Increasing breast cancer and melanoma incidence and mortality rates has lead to improved public health policies and awareness [9, 10]. Plant derived medicines have less or no toxicity on normal cells and used as chemotherapeutic or chemo-preventive supplements [11]. Water extracts of the fruit aril has anticancer activity against colon cancer by inducing necrosis [12] but the effects on other cancers such as melanoma and breast is unknown. Therefore the aim of this study was to elucidate the effect of varietal variations on carotenoids and anticancer properties of M. cochinchinensis from Australia, Thailand and Vietnam.

\section{MATERIALS AND METHODS}

Plants were collected from rural and metropolitan provinces as previously detailed [4] and prepared for HPLC or cell culture assays.

\section{A. Extraction}

1) Crude hexane extract for HPLC: Carotenoids were extracted using a method described previously [13]. The aril $(2 \mathrm{~g})$ was placed in a vessel protected from sunlight and mixed with $100 \mathrm{~mL}$ of extraction solvent (hexane/acetone/ethanol: 50:25:25 v/v/v) [13]. The mixture was ultra-sonicated (Unisonics, Australia) for $30 \mathrm{~min}$ and then $15 \mathrm{~mL}$ of distilled water was added to enhance phase separation whereby the upper organic layer contained carotenoids and the bottom water layer contained cell debris. The upper organic layer was evaporated to dryness and the residue was dissolved in THF/acetonitrile/methanol: 50:25:25 v/v/v to a final volume of $4 \mathrm{~mL}$ for HPLC analysis.

2) Crude water extract for cell culture: $15 \mathrm{M}$. cochinchinensis aril samples from different provinces were used to extract. The frozen sample $(2 \mathrm{~g})$ was placed in a vessel, protected from sunlight and mixed with $100 \mathrm{~mL}$ of deionised water. The mixture was sonicated for $30 \mathrm{~min}$, filtered and evaporated to dryness. The crude extract was 
dissolved in milliQ water and mixed using water-bath sonicator (Unisonics, Australia) for $10 \mathrm{~min}$ and filter sterilised using $0.1 \mu \mathrm{m}$ filters and diluted to $1 \mathrm{mg} / \mathrm{ml}$ in sterile water.

\section{B. HPLC analysis of carotenoids}

Carotenoid extracts were analysed via reversed phase HPLC using solvents and isocratic conditions as described previously [13]. Analysis was performed using an isocratic HPLC method $(90 \% \mathrm{CH} 3 \mathrm{CN} / \mathrm{H} 2 \mathrm{O})$ on an Alltech Alltima HP C18 $(250$ x 4.6) $5 \mu$ column at a flow rate of $1.0 \mathrm{~mL} / \mathrm{min}$. HPLC analyses were performed on a Dionex P680 solvent delivery system equipped with a PDA100 UV detector (operated using "Chromeleon" software). The column temperature was $30^{\circ} \mathrm{C}$ and UV detection was at $465 \mathrm{~nm}$. Concentrations of lycopene and $\beta$-carotene were quantified by reference to commercial standards of lycopene and $\beta$ carotene (Sigma Chemical, St. Louis, USA).

\section{Cytotoxicity assay on melanoma and breast cancer cells}

Cytotoxicity of cancer cells were determined by CCK-8 assay using Cell Counting Kit-8 (CCK-8; Dojindo Molecular Technology, Gaithersburg, MD). The melanoma (MM418C1, D24) and breast cancer (MCF7) cells were seeded in 96 well plates containing 10\% FBS DMEM and RPMI (Invitrogen) media at 5000 cells/well and 3000 cells/well, respectively. Cells were permitted to adhere for $24 \mathrm{~h}$ at $37{ }^{\circ} \mathrm{C}$ in $5 \% \mathrm{CO} 2$ and then treated with $1 \mathrm{mg} / \mathrm{ml}$ of water extract. Concurrent control cells were cultured in medium only. After treatment, all plates were incubated for $72 \mathrm{~h}$. Cytotoxicity assay was determined after incubation in $37^{\circ} \mathrm{C}$ for $2 \mathrm{~h}$ with CCK-8 reagents and the absorbance was measured spectrophotometrically at $450 \mathrm{~nm}$ using CLARIOstar ${ }^{\circledR}$ High Performance Monochromator Multimode Microplate Reader (BMG LABTECH). Data was presented as proportional viability $(\%)$ by comparing the treated cells with the untreated cells (control), where the viability was $100 \%$ in untreated cells. All tests and analyses were duplicated.

\section{Statistical analysis}

Quantification of lycopene and $\beta$-carotene from HPLC was analysed using Minitab statistical software (version 16). For normally distributed data, a one-way analysis of variance (ANOVA) with least significant differences (LSD) from Fishers test was conducted using the equation: $\mathrm{LSD}_{0.05}=t \sqrt{\frac{2 x M S E}{n}}$, where $\mathrm{t}$ was 2-tailed values at $\mathrm{P}=0.05$; $\mathrm{MSE}=$ least square error from ANOVA, $\mathrm{n}=$ replicate number. Not normally distributed data was transformed or analysed using Kruskal Wallis method. Statistical values of $\mathrm{P} \leqslant 0.05$ were considered as significantly different

\section{RESULTS AND DISCUSSION}

\section{A. Carotenoid content}

The carotenoid content of crude extracts in this study was highly variable, ranging from 0.88 to $6.30 \mathrm{mg} / \mathrm{g}$ for lycopene and 0.25 to $5.70 \mathrm{mg} / \mathrm{g}$ for $\beta$-carotene (Fig. 1). The highest lycopene content was observed in samples collected from Lam Ha $(6.3 \mathrm{mg} / \mathrm{g})$ and Lam Dong $(6.20 \mathrm{mg} / \mathrm{g})$ provinces of Central Vietnam, three times greater than previously reported for the same species [14] and 200 times greater than hydroponic tomatoes [15]. The highest $\beta$-carotene content was from Hoa Binh $(5.70 \mathrm{mg} / \mathrm{g})$ province in Northern Vietnam, almost eight times greater than previously reported from the same species [14] and 54 times greater than carrots [17].

The nutritional superiority of cultivars from specific provinces in Central and Northern Vietnam may possibly be an adaptation mechanism to increase cellular and metabolic protection for survival at higher altitudes and suboptimal temperatures as observed in other economically valuable fruits [18-20]. What these mechanisms are and how it influences the carotenoid synthesis pathway in $\mathrm{M}$. cochinchinensis are unknown and unraveling the mystery could improve our understanding on plant responses to environmental stress. Highlighting these regions of interest that contain valuable superior varieties is the first step for conservation of the existing populations to facilitate a sustainable and consistent high quality product as an alternative functional food that shadows even tomatoes and carrots commonly associated with high nutritional value.

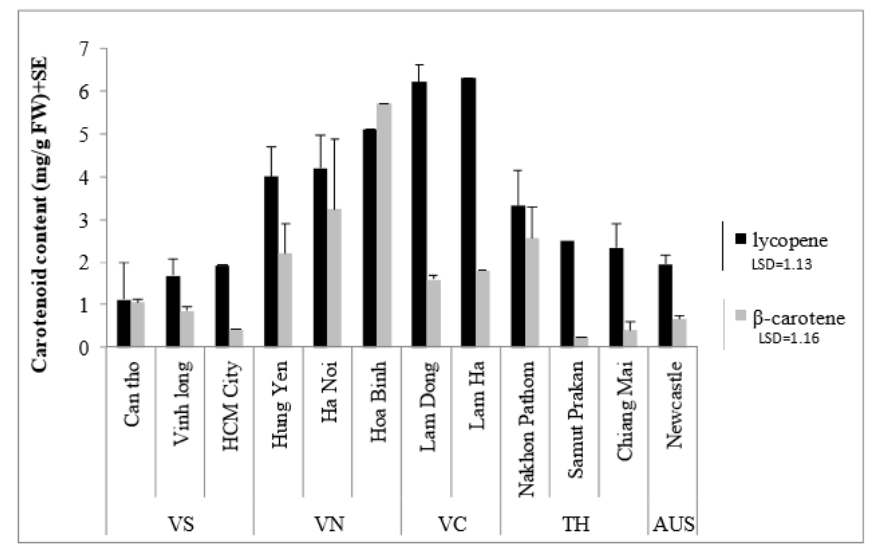

Fig. 1 Lycopene and $\beta$-carotene content in $\mathrm{M}$. cochinchinensis aril from provinces in Vietnam (VS=Southern Vietnam, VN=Northern Vietnam, $\mathrm{VC}=$ Central Vietnam), Thailand (TH) and Australia (AU) quantified using HPLC. Fisher's LSD (least significance differences) values were generated from transformed data of lycopene $(\mathrm{df}=16, \mathrm{~F}=2.72, \mathrm{p}=0.01)$ and $\beta$-carotene $(\mathrm{df}=16, \mathrm{~F}=4.18, \mathrm{p}=0.000)$.

\section{B. Anti-cancer activity}

The cytotoxicity of crude plant extracts on cancer cells were variable and significantly affected by varietal differences ranging from $0-71 \%$ loss in cell viability (Fig. 2). Extracts specifically from Northern and Central Vietnam significantly reduced cancer cell viability and subsequently cell growth, by up to $70 \%$ relative to controls and was suggestive of anticancer activity. This dramatic reduction in cell viability might be through necrotic [12] or apoptotic cellular pathways $[21,22]$ which will be confirmed in future studies with the analysis of morphology and biochemical tests.

The greatest cytotoxicity was from Northern Vietnam with $60 \%$ and $71 \%$ mortality on breast cancer and melanoma cells, respectively (Fig. 2). These same samples also produced the highest $\beta$-carotene which was unlikely to be the bioactive compound since $\beta$-carotene is water insoluble [23] and possibly might be due a protein as reported in a previous studies in M. cochinchinensis aril and seeds [12, 24, 
25]. The responsible compound for the cytotoxicity observed in this study from the aril has not been studied before and further fractionation and purification is necessary to determine the bioactive protein is the same.

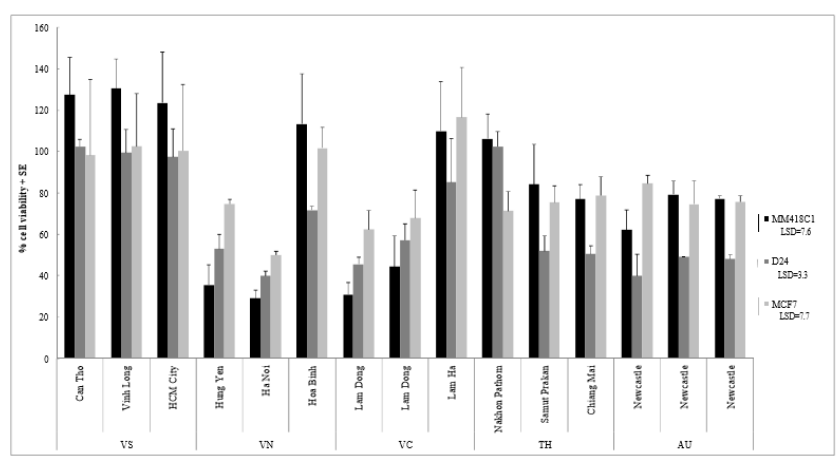

Fig. 2 Cytotoxicity of Momordica cochinchinensis crude water extract from provinces in Vietnam (VS=Southern Vietnam, VN=Northern Vietnam, $\mathrm{VC}=$ Central Vietnam), Thailand $(\mathrm{TH})$ and Australia (AU) on melanoma (MM418C1, D24) and breast cancer (MCF7) cells. Data was presented relative to controls without treatment. Fisher's LSD (least significance differences) values were generated from untransformed data of MM418C1 $(\mathrm{df}=14, \mathrm{~F}=10.42, \mathrm{p}=0.000), \mathrm{D} 24(\mathrm{df}=14, \mathrm{~F}=15.58, \mathrm{p}=0.000)$ and MCF7 $(\mathrm{df}=14, \mathrm{~F}=2.22, \mathrm{p}=0.000)$.

\section{CONCLUSIONS}

The carotenoid content and anticancer potential in the aril of M. cochinchinensis was highly variable and likely an expression of genetic and phenotypic differences. This study achieved the aims in that 1) important cultivars were identified from existing wild and cultivated populations, 2) regions that produced highly nutritious and bioactive fruits were identified for replication in agriculture, specifically Central and Northern Vietnam, and 3) the extent of variation in carotenoids and bioactivity of aril compared to common fruits and vegetables. This study provided vital information on collection sites of M. cochinchinensis which possess the highest nutritional and bioactivity for future breeding and crop improvement.

\section{ACKNOWLEDGMENT}

We are grateful for the support from Thu Nga Nguyen and Huong Nguyen in (Hanoi University of Agriculture), Nonnipa Labbunruang and Wanisika Phadungsii (Tammasat University) and Thuy-em Pham (Saigon) for collection assistance; Duc Nguyen (Hanoi University of Agriculture) for access and the use of laboratory facilities, Cuong Nguyen (Hanoi University of Agriculture) for agronomy advice; Rattanapong Charntawong (Thailand gac farm), Dr Sophie Parks (NSW Department of Primary Industries, Australia) and Professor Minh Nguyen for providing $M$. Cochinchinensis fruits. We thank RMIT University for the travel grant awarded to Tien Huynh for sample collection.

\section{REFERENCES}

[1] Kubola, J., N. Meeso, and S. Siriamornpun, Lycopene and beta carotene concentration in aril oil of gac (Momordica cochinchinensis Spreng) as influenced by aril-drying process and solvents extraction. Food Research International, 2013. 50(2): p. 664-669.
[2] Chuyen, H.V., et al., Gac fruit (Momordica cochinchinensis Spreng.): a rich source of bioactive compounds and its potential health benefits. International Journal of Food Science \& Technology, 2015. 50(3): p. 567-577.

[3] Bootprom, N., et al., Molecular diversity among selected Momordica cochinchinensis (Lour.) Spreng accessions using RAPD markers. SABRAO Journal of Breeding and Genetics, 2012. 44(2): p. 406-104.

[4] Wimalasiri, D., et al., Morphological and genetic diversity of Momordica cochinchinenesis (Cucurbitaceae) in Vietnam and Thailand. Genetic Resources and Crop Evolution, 2015: p. 1-15.

[5] Aoki, H., et al., Carotenoid Pigments in GAC Fruit (Momordica cochinchinensis SPRENG). Bioscience Biotechnology and Biochemistry, 2002. 66: p. 2479-2482.

[6] Rao, A.V. and S. Agarwal, Role of lycopene as antioxidant carotenoid in the prevention of chronic diseases: A review. Nutrition Research, 1999. 19(2): p. 305-323.

[7] Hammond, B.R. and L.M. Renzi, Carotenoids. Advances in Nutrition, 2013. 4(4): p. 474-476.

[8] Giovannucci, E., et al., Intake of carotenoids and retinol in relation to risk of prostate cancer. J Natl Cancer Inst, 1995. 87(23): p. 1767-76.

[9] Stracci, F., et al., Incidence, mortality and survival trends of cutaneous melanoma in Umbria, Italy. 1978-82 and 1994-98. Tumori, 2005. 91(1): p. 6-8.

[10] Ayob, Z., et al., Cytotoxic Activities against Breast Cancer Cells of Local Justicia gendarussa Crude Extracts. Evidence-based Complementary and Alternative Medicine : eCAM, 2014. 2014: p. 732980.

[11] Bhanot, A., R. Sharma, and M.N. Noolvi, Natural sources as potential anti-cancer agents: A review. International journal of phytomedicine, 2011. 3(1): p. 09-26

[12] Tien, P.G., et al., Inhibition of tumor growth and angiogenesis by water extract of Gac fruit (Momordica cochinchinensis Spreng). Int J Oncol, 2005. 26(4): p. 881-9.

[13] Barba, A., et al., Application of a UV-vis detection-HPLC method for a rapid determination of lycopene and $\beta$-carotene in vegetables. Food Chemistry, 2006. 95(2): p. 328-336.

[14] Ishida, B.K., et al., Fatty acid and carotenoid composition of gac (Momordica cochinchinensis Spreng) fruit. Journal of Agricultural and Food Chemistry, 2004. 52(2): p. 274-279.

[15] Javanmardi, J. and C. Kubota, Variation of lycopene, antioxidant activity, total soluble solids and weight loss of tomato during postharvest storage. Postharvest biology and technology, 2006. 41(2): p. 151-155.

[16] Adams-Phillips, L., C. Barry, and J. Giovannoni, Signal transduction systems regulating fruit ripening. Trends Plant Sci, 2004. 9: p. 331 338.

[17] Gul, K., et al., Chemistry, encapsulation, and health benefits of ßcarotene - A review. Cogent Food \& Agriculture, 2015. 1(1): p. 1018696.

[18] Pereira, A.P., et al., Phenolic compounds and antimicrobial activity of olive (Olea europaea L. Cv. Cobrancosa) leaves. Molecules, 2007. 12(5): p. 1153-62.

[19] Jaakola, L. and A. Hohtola, Effect of latitude on flavonoid biosynthesis in plants. Plant, Cell \& Environment, 2010. 33(8): p. 1239-1247.

[20] Cechin, I., V.d.J. Rocha, and T.d.F. Fumis, Sensitivity of yellow passion fruit to ultraviolet-B radiation. Pesquisa Agropecuária Brasileira, 2012. 47: p. 1422-1427.

[21] Han, S.I., Y.-S. Kim, and T.-H. Kim, Role of apoptotic and necrotic cell death under physiologic conditions. BMB Rep, 2008. 41(1): p. 110 .

[22] Hippert, M.M., P.S. O'Toole, and A. Thorburn, Autophagy in cancer: good, bad, or both? Cancer Res, 2006. 66(19): p. 9349-51.

[23] Rodriguez-Amaya, D.B. and M. Kimura, HarvestPlus handbook for carotenoid analysis. 2004: International Food Policy Research Institute (IFPRI).

[24] Chuethong, J., et al., Cochinin B, a novel ribosome-inactivating protein from the seeds of Momordica cochinchinensis. Biol Pharm Bull, 2007. 30(3): p. 428-32.

[25] Bolognesi, A., et al., Purification and properties of a new ribosomeinactivation protein with RNA N-glycosidase activity suitable for immunotoxin preparation from the seeds of Momordica cochinchinensis. Biochimica et Biophysica Acta (BBA) - General Subjects, 1989. 993(2-3): p. 287-292. 